\title{
Production of DOC by Calanus finmarchicus, C. glacialis and $C$. hyperboreus through sloppy feeding and leakage from fecal pellets
}

\author{
Eva Friis Møller ${ }^{1,2, *}$, Peter Thor ${ }^{3}$, Torkel Gissel Nielsen ${ }^{1}$ \\ ${ }^{1}$ National Environmental Research Institute, Department of Marine Ecology, Frederiksborgvej 399, PO Box 358, \\ 4000 Roskilde, Denmark \\ ${ }^{2}$ University of Aarhus, Department of Marine Ecology, Finlandsgade 14, 8200 Århus, Denmark \\ ${ }^{3}$ Göteborg University, Department of Marine Ecology, Kristineberg Marine Research Station, 45035 Fiskebäckskil, Sweden
}

\begin{abstract}
Using ${ }^{14}$ C-labeled phytoplankton as tracer, we investigated 2 mechanisms of immediate dissolved organic carbon (DOC) release during grazing activity of Calanus spp. — sloppy feeding and leakage from newly expelled fecal pellets. Half of the carbon cleared by Calanus spp. was released as DOC through sloppy feeding. Freshly expelled fecal pellets lost more than $20 \%$ of their carbon content within the first hour, corresponding to $6 \%$ of the carbon cleared. Thus, copepods should not only be considered as an essential link to higher trophic levels, but also as a feedback link to the microbial food web.
\end{abstract}

KEY WORDS: Dissolved organic carbon · DOC · Sloppy feeding · Fecal pellets · Calanus spp. Resale or republication not permitted without written consent of the publisher

\section{INTRODUCTION}

The classical assumption that large marine copepods primarily act as link between primary producers and higher trophic levels has recently been challenged by documentation of significant production of dissolved organic material (DOM) by grazing copepods. High production rates of DOM have been recorded during the spring bloom (Hasegawa et al. 2001) and in the laboratory when copepods feed on large phytoplankton species (Møller \& Nielsen 2001). In contrast, grazing on smaller species leads to insignificant DOM production rates (Strom et al. 1997, Møller \& Nielsen 2001). Several mechanisms contribute to the production of DOM, including sloppy feeding, ammonium excretion, and leakage from fecal pellets. Previously, only the total amount of DOM produced by copepods or the contribution of their fecal pellets has been quantified, and experimental discrimination between the different sources has not been made. Working with freshwater cladocerans, however, Lampert (1978) distinguished between DOC produced by sloppy feeding and by excretion and leaching from fecal pellets.
In a much-cited theoretical paper, Jumars et al. (1989) suggested that more than $50 \%$ of the solutes in fecal pellets leak out within $5 \mathrm{~min}$, but to our knowledge this theory has not yet been experimentally tested. Urban-Rich (1999) measured Calanus spp. fecal pellets produced within $6 \mathrm{~h}$ of egestion and reported an $86 \%$ reduction in the fecal pellet DOC pool within the subsequent $6 \mathrm{~h}$. In contrast, Strom et al. (1997) could not measure any leakage of DOC from Calanus pacificus pellets during the same period.

DOM-production comprises an important source of substrate for the bacterial community. Experiments have shown that the presence of grazing copepods enhances bacterial production and correlates with increased bacterial biomass (Eppley et al. 1981, Roman et al. 1988, Peduzzi \& Herndl 1992). In the field, the vertical distributions of copepods in the water column have been found to match the distribution of amino acids (Poulet et al. 1991) and bacterial numbers and activity (T. G. Nielsen et al. unpubl.).

Copepods of the genus Calanus are key organisms of high-latitude pelagic ecosystems, especially during and just after the spring bloom, when they dominate 
the grazer community (Madsen et al. 2001). The aim of the present study was to quantify the immediate DOC production by C. finmarchicus, C. glacialis and C. hyperboreus by sloppy feeding and leakage from newly expelled fecal pellets during simulated springbloom conditions in the laboratory.

\section{MATERIALS AND METHODS}

Sampling. Phytoplankton and copepods were collected in June 2001 in Disko Bay off the western coast of Greenland at a $250 \mathrm{~m}$ deep station located 1 nautical mile from Qeqertarsuaq (Godhavn) (69 $15^{\prime} \mathrm{N}$, $53^{\circ} 33^{\prime} \mathrm{W}$ ). For a description of the area and the pelagic ecology of Disko Bay see Nielsen \& Hansen (1995), Madsen et al. (2001) and Levinsen \& Nielsen (2002). Phytoplankton were sampled from the subsurface fluorescence peak (between 12 and $45 \mathrm{~m}$ ) using a $30 \mathrm{l}$ Niskin bottle. The copepods were collected in the upper $50 \mathrm{~m}$ with a WP-2 net $(200 \mu \mathrm{m})$ with a large nonfiltering cod-end, and were subsequently diluted with surface water in a thermo-box. All samples were kept cold and shaded and were brought to the laboratory within $3 \mathrm{~h}$.

Laboratory conditions. In the laboratory, all incubations and experiments were carried out in dim light in a temperature-controlled room at 0 to $2^{\circ} \mathrm{C}$. Upon arrival at the laboratory, Calanus finmarchicus, C. glacialis and C. hyperboreus females were immediately sorted out, and were kept in 51 beakers at 5 to 10 individuals $\mathrm{l}^{-1}$ and fed natural plankton until the start of the experiment the next day. The sampled water was reversefiltered through a $200 \mu \mathrm{m}$ screen with added B1medium with Si (Hansen 1989) along with $100 \mu \mathrm{Ci}$ $\mathrm{NaH}^{14} \mathrm{CO}_{3} \mathrm{l}^{-1}$. The filtered water was then incubated for 3 to $4 \mathrm{~d}$ at a photon flux density of $320 \mu \mathrm{mol} \mathrm{m}^{-2} \mathrm{~s}^{-1}$, resulting in $4.6 \pm 0.9 \mathrm{SE}$ doublings (measured as an increase in chlorophyll a), which were sufficient to ensure a uniform labeling of the phytoplankton community (Nielsen \& Olsen 1989)

To remove dissolved ${ }^{14} \mathrm{C}$, the incubated phytoplankton was washed prior to the experiment following the procedure described by Møller \& Nielsen (2001). In brief, the labeled plankton community was placed in a $1.2 \mathrm{l}$ chamber below a $10 \mu \mathrm{m}$ screen and $5 \mathrm{l}$ of $0.2 \mu \mathrm{m}$ filtered seawater was pumped through the chamber by a peristaltic pump (100 $\left.\mathrm{ml} \mathrm{min}^{-1}\right)$.

Measurements. Isotopic activity was measured in $8 \mathrm{ml}$ subsamples separated into particulate organic carbon POC and DOC by filtration through GF/F filters. The filters were transferred to scintillation vials and preserved with $1 \mathrm{ml}$ of $23 \%$ formaldehyde. The filtrate was preserved with $0.5 \mathrm{ml}$ of $23 \%$ formaldehyde. Inorganic ${ }^{14} \mathrm{C}$ was removed by adding $300 \mu \mathrm{l} 1 \mathrm{~N} \mathrm{HCl}_{\text {, }}$ leaving the vials without lids for $24 \mathrm{~h}$ prior to the addition of $12 \mathrm{ml}$ of Packard Ultima Gold XR scintillation cocktail. The activity was assessed by liquid scintillation counting in a Beckman LS 1801 scintillation counter. The amount of organic carbon $(\mu \mathrm{g} C)$ used in calculation of DOC and POC concentrations and DOC production rates was calculated by dividing the isotopic activity of the samples (dpm) with the specific activity of the washed phytoplankton $\left(\mathrm{dpm} \mu \mathrm{g} \mathrm{C}^{-1}\right)$. The specific activity of the washed phytoplankton was calculated by dividing the measured activity of the phytoplankton samples with the carbon content $\left(\mu \mathrm{gC} \mathrm{ml}^{-1}\right)$. The carbon content was measured in triplicate $40 \mathrm{ml}$ subsamples of the washed phytoplankton filtered onto precombusted GF/F filters using a Carlo Erba Elemental Analyzer (EA 1108). Chlorophyll was measured in duplicate $20 \mathrm{ml}$ subsamples according to Jespersen \& Christoffersen (1987). The phytoplankton composition was examined under an inverted microscope.

Sloppy feeding. We performed 5 experiments (S1 to S5) with the natural plankton community and 1 experiment (S6) with a single cell culture of Thalassiosira gravida (Scandinavian Culture Centre for Algae and Protozoa, University of Copenhagen). Prior to incubation, copepods were starved for a minimum of $6 \mathrm{~h}$ to empty their guts. In each experiment, 5 females of each Calanus species were incubated individually in $62 \mathrm{ml}$ cell-culture bottles (Nunc) for 30 min with washed ${ }^{14} \mathrm{C}$ labeled phytoplankton; 5 control bottles contained only ${ }^{14}$ C-labeled phytoplankton. Copepods were handled very gently and did not seem to be stressed by handling, as they began feeding immediately after being added to the bottle. At the beginning and end of the experiment, isotopic activity of the phytoplankton was measured in $8 \mathrm{ml}$ subsamples filtered through GF/F filters following the procedure described above.

The chosen incubation time of 30 min was shorter than the expected gut-evacuation time (Maar et al. 2002) so that all $\mathrm{DO}^{14} \mathrm{C}$ production by the copepods could be assigned to their handling of the food. To ensure that this was actually the case, we checked at the end of the incubation periods to ensure that no fecal pellets had been produced during the experiment. If pellets were found, then the experiment was excluded from the data set. Excretion was not addressed in the sloppy feeding experiments, as they ran for 30 min only, an insufficient period for the labeled carbon to reach potential excretion products.

Individual copepods were transferred to scintillation vials, scintillation cocktail was added and the isotopic activities of the copepods were measured. Ingestion rate $(I)$, i.e. the amount of carbon accumulated in the copepod gut per unit of water per unit time $\left(I_{,} \mu \mathrm{C} \mathrm{C} \mathrm{ml}^{-1}\right.$ $\mathrm{h}^{-1}$ ), was calculated from the isotopic activity of the copepods. 
The average (avg) POC concentration $\left(\mathrm{POC}_{\mathrm{avg}}, \mu \mathrm{gC}\right.$ $\mathrm{ml}^{-1}$ ) was calculated following the method of Frost (1972) simplified by Kiørboe et al. (1982) in the control $\left(\mathrm{POC}_{P \text {-avg }}\right.$ ) and copepod-containing bottles $\left(\mathrm{POC}_{C \text {-avg }}\right.$ ) from the POC concentration at the start $\left(\mathrm{POC}_{\text {start }}\right)$ and the end $\left(\mathrm{POC}_{\mathrm{end}}\right)$ of the incubation:

$$
\mathrm{POC}_{\mathrm{avg}}=\frac{\mathrm{POC}_{\mathrm{end}}-\mathrm{POC}_{\text {start }}}{\ln \left(\mathrm{POC}_{\mathrm{end}}\right)-\ln \left(\mathrm{POC}_{\text {start }}\right)}
$$

The DOC production rate by phytoplankton, i.e. the amount of DOC produced per POC per time $\left(\mathrm{DOC}_{P_{1}}\right.$

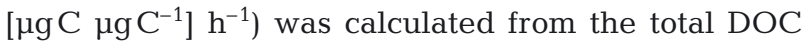
production $\left(\mathrm{DOC}_{T}, \mu \mathrm{g} \mathrm{C} \mathrm{ml} \mathrm{C}^{-1} \mathrm{~h}^{-1}\right.$ ) in the control bottles as:

$$
\mathrm{DOC}_{P}=\frac{\mathrm{DOC}_{T}}{\mathrm{POC}_{P \text {-avg }}}
$$

DOC production by the copepods, i.e. the amount of DOC produced due to grazing per unit volume of water per unit time $\left(\mathrm{DOC}_{C}, \mu \mathrm{gC} \mathrm{ml} \mathrm{C}^{-1} \mathrm{~h}^{-1}\right)$ was calculated taking into account the DOC production by phytoplankton in the copepod-containing bottle:

$$
\mathrm{DOC}_{C}=\mathrm{DOC}_{T}-\mathrm{DOC}_{P} \times \mathrm{POC}_{C \text {-avg }}
$$

The DOC loss rate was calculated from the slope $(a$, $\mu \mathrm{gC}[\mu \mathrm{gC} \text { ingested }]^{-1}$ ) of the linear regression between ingestion/gut content $(I)$ and DOC production $\left(\mathrm{DOC}_{C}\right)$.

$$
\mathrm{DOC}_{C}=a \times I
$$

It also important to determine the DOC production expressed as fraction of the carbon removed from suspension (RFS, $\mu \mathrm{gC} \mathrm{ml}^{-1} \mathrm{~h}^{-1}$ ), i.e. the total food carbon removed per unit volume of water per unit time, which is equal to the ingestion/gut content $(I)$ plus the DOC produced by grazing $\left(\mathrm{DOC}_{C}\right)$ :

$$
\mathrm{RFS}=\mathrm{DOC}_{C}+I
$$

By combining Eqs. (4) \& (5), the loss of DOC as a fraction of RFS ( $\mu \mathrm{gC}[\mu \mathrm{g} \mathrm{C} \mathrm{RFS}]^{-1}$ ) can be calculated:

$$
\mathrm{DOC}_{C}=\frac{a}{a+1} \times \mathrm{RFS}
$$

Since we used in situ populations of plankton for our incubations, protozooplankton were also included. This was the case in both the control bottles and the experimental bottles. If the feeding of copepods on protozooplankton is substantial, this could lead to an underestimation of the DOC loss caused by copepods because the biomass and thus feeding activity of the protozooplankton would be highest in incubations without copepods (Nejstgaard et al. 2001).

Leakage from fecal pellets. Female copepods were incubated with the labeled plankton in a 51 container with a false $500 \mu \mathrm{m}$ screen bottom. The copepods were allowed to feed for 3 to $4 \mathrm{~h}$ to replace their gut content with ${ }^{14} \mathrm{C}$-labeled plankton. To rinse the copepods, the false bottom with the copepods was transferred to $0.5 \mu \mathrm{m}$ filtered seawater. The copepods were then gently transferred to a $10 \mathrm{~cm}$ petri dish with $0.5 \mu \mathrm{m}$ filtered seawater from which all fecal pellets produced during handling were removed. The copepods were observed under a dissecting microscope and fecal pellets were collected immediately after egestion (within $10 \mathrm{~s}$ ) using a mouth pipette, and were transferred to $8 \mathrm{ml} 0.5 \mu \mathrm{m}$ filtered seawater in a $10 \mathrm{ml}$ glass vial. Triplicate samples of 10 fecal pellets were transferred to each vial; the total collection took less than $5 \mathrm{~min}$. The experiment was stopped by filtration onto $\mathrm{GF} / \mathrm{F}$ filters and the isotopic activities of the filter and the filtrate were measured.

Incubations of pellets were performed for periods of $0,15,30$ and $60 \mathrm{~min}$. Due to the handling time the measurement at one time interval, $t$, represents the leakage from pellets that had been leaking DOC between $t$ and a maximum of $t+5 \mathrm{~min}$. Leakage is presented in relation to the middle point of the time interval (see Fig. 2). Leakage of DOC from the fecal pellets was calculated from the $\mathrm{DOC} /(\mathrm{DOC}+\mathrm{POC})$ ratio in each individual incubation; since each incubation contained a different volume of fecal pellet carbon, a normalization was necessary.

Fecal pellet experiments were performed only with Calanus finmarchicus (F2) and C. glacialis (F1) as C. hyperboreus did not produce enough fecal pellets to carry out this study. This may have been due to the fact that $C$. hyperboreus was at this time preparing to overwinter (Niehoff et al. 2002).

\section{RESULTS}

The phytoplankton biomass in the experiments varied between 650 and $2330 \mu \mathrm{g} \mathrm{C}^{-1}$ and was dominated by diatoms species characteristic for the spring bloom in Disko Bay (Levinsen et al. 2000) (Table 1).

\section{Sloppy feeding}

DOC production by copepods increased as a function of their ingestion (Fig. 1). Negative DOC production values are due to low production of DOC by the copepods relative to the subtracted DOC production by phytoplankton (see 'Materials and Methods'). However, they do not affect the calculations of the release rate, since the latter are based solely on the slope of the regressions. The regression statistic and the DOC production expressed as a fraction of ingested carbon or of carbon removed from suspension are summarized in 


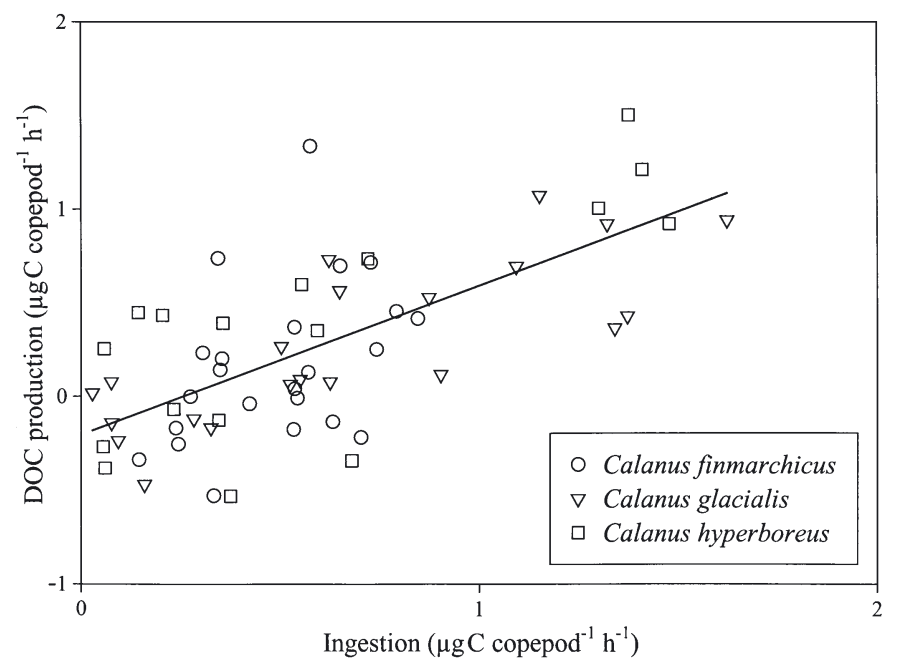

Fig. 1. Calanus spp. DOC production by sloppy feeding as a function of ingestion rate (Regressions and statistics in Table 2)

Table 2. The experiment with the diatom culture (S6) was excluded from the overall regressions since we wanted to estimate the DOC production by sloppy feeding on a natural plankton community. It is included in Table 2 only to scale the results of the experiments with natural phytoplankton to those of routine laboratory experiments based on cultured algae.

The remaining data indicated that Calanus spp. lost $49 \%$ of the carbon they removed from suspension. The individual regressions for the 3 species gave comparable loss rates (Table 2). The slopes of the regressions for all 3 species were not significantly different (Student's $t$-test between the individual regressions: $p>0.1$ ). If alternative regressions are made from each

Table 1. Phytoplankton concentration and composition in experiments determining DOC production by sloppy feeding (Expts S1 to S6) and leakage from fecal pellets (Expts F1 and F2). Date: sampling date (2001); Biomass: initial experimental biomass

\begin{tabular}{|c|c|c|c|}
\hline Expt & Date & $\begin{array}{l}\text { Biomass } \\
\mu \mathrm{g} \mathrm{C}^{-1}\end{array}$ & $\begin{array}{l}\text { Dominant } \\
\text { species }\end{array}$ \\
\hline $\mathrm{S} 1, \mathrm{~F} 1$ & June 6 & 1998 & $\begin{array}{l}\text { Thalassiosira spp. } \\
\text { Chaetoceros spp. }\end{array}$ \\
\hline $\mathrm{S} 2$ & June 10 & 1524 & $\begin{array}{l}\text { Thalassiosira spp. } \\
\text { Chaetoceros spp. }\end{array}$ \\
\hline S3, F2 & June 11 & 653 & $\begin{array}{l}\text { Thalassiosira spp. } \\
\text { Chaetoceros spp. }\end{array}$ \\
\hline $\mathrm{S} 4$ & June 17 & 767 & $\begin{array}{l}\text { Chains of pennate } \\
\text { diatoms }\end{array}$ \\
\hline S5 & June 20 & 943 & $\begin{array}{l}\text { Thalassiosira spp. } \\
\text { Chaetoceros spp. }\end{array}$ \\
\hline S6 & Culture & 2333 & T. gravida \\
\hline
\end{tabular}

experimental date using the data from all 3 species of Calanus the loss of DOC varies more, but with weaker statistical power, probably because of the smaller sample numbers (Table 2).

\section{Leakage of DOC from fecal pellets}

For Calanus finmarchicus fecal pellets, the DOC/ (DOC + POC) ratio increased from 0.13 at the first measurement to a maximum of 0.28 after $15 \mathrm{~min}$. For C. glacialis pellets, the $\mathrm{DOC} /(\mathrm{DOC}+\mathrm{POC})$ ratio increased from 0.05 to 0.24 after 60 min (Fig. 2). A hyperbolic equation proved the best fit of the data:

\section{Calanus finmarchicus:}

$$
\frac{\mathrm{DOC}}{\mathrm{DOC}+\mathrm{POC}}=\frac{0.28 \pm 0.03 \times t}{2.46 \pm 1.95+t}, \mathrm{r}^{2}=0.36, \mathrm{p}=0.039
$$

\section{Calanus glacialis:}

$$
\frac{\mathrm{DOC}}{\mathrm{DOC}+\mathrm{POC}}=\frac{0.41 \pm 0.16 \times t}{44.3 \pm 33.8+t}, \mathrm{r}^{2}=0.79, \mathrm{p}=0.001
$$

where $t$ is time in minutes.

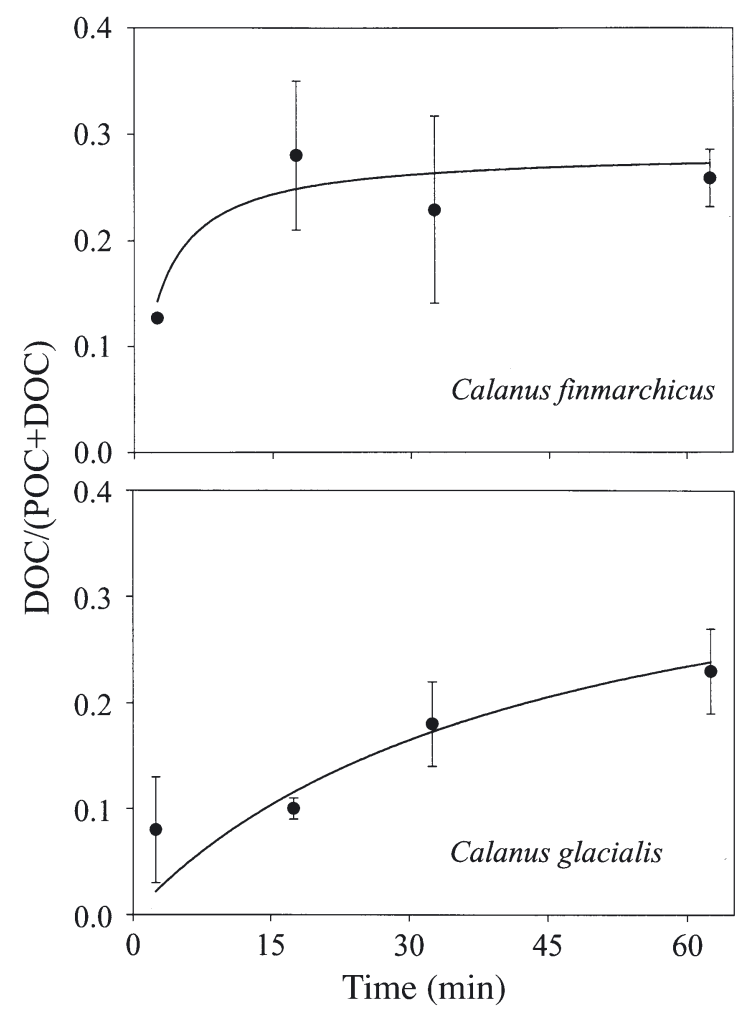

Fig. 2. Calanus spp. Mean $\left( \pm \mathrm{SE}_{\mathrm{i}} \mathrm{n}=3\right) \mathrm{DOC}$ production by leakage from fecal pellets presented as the DOC/(DOC+POC) ratio as function of time. For C. finmarchicus at $2.5 \mathrm{~min}, \mathrm{n}=2$ and error bar was too small to be included 
Table 2. Calanus spp. DOC production by sloppy feeding. Loss rate expressed either as slope (a) of linear regression between DOC production and carbon ingestion (Fig. 3) or as fraction of carbon removed from suspension: $a /(a+1)$. Statistic is for the determination of slope a. (-S6): Expt 6 excluded; Removed: removed from suspension. For further details see 'Materials and methods'

\begin{tabular}{|c|c|c|c|c|c|}
\hline \multirow[t]{2}{*}{ Expt } & \multicolumn{2}{|c|}{ DOC-production } & \multirow[t]{2}{*}{$\mathrm{n}$} & \multirow[t]{2}{*}{$\mathrm{r}^{2}$} & \multirow[t]{2}{*}{$\mathrm{p}$} \\
\hline & $\begin{array}{c}\text { Ingested }^{-1} \\
a \pm \mathrm{SE}\end{array}$ & $\begin{array}{c}\text { Removed }^{-1} \\
a /(a+1)\end{array}$ & & & \\
\hline All (-S6) & $0.97 \pm 0.10$ & 0.49 & 61 & 0.57 & $<0.0001$ \\
\hline C. finmarchicus (-S6) & $0.90 \pm 0.42$ & 0.48 & 23 & 0.14 & 0.04 \\
\hline C. glacialis $(-\mathrm{S} 6)$ & $0.69 \pm 0.12$ & 0.41 & 21 & 0.63 & $<0.0001$ \\
\hline C. hyperboreus (-S6) & $0.90 \pm 0.19$ & 0.47 & 17 & 0.59 & 0.0003 \\
\hline S1 & $1.19 \pm 0.28$ & 0.54 & 11 & 0.67 & 0.02 \\
\hline S2 & $0.25 \pm 0.54$ & 0.20 & 12 & 0.02 & 0.64 \\
\hline S3 & $0.67 \pm 0.58$ & 0.40 & 10 & 0.14 & 0.28 \\
\hline S4 & $0.35 \pm 0.17$ & 0.26 & 13 & 0.29 & 0.06 \\
\hline S5 & $0.39 \pm 0.15$ & 0.28 & 15 & 0.34 & 0.02 \\
\hline S6 (culture) & $1.01 \pm 0.36$ & 0.50 & 20 & 0.28 & 0.01 \\
\hline
\end{tabular}

carbon removed from suspension was lost by sloppy feeding. Assimilation efficiency is assumed to be $60 \%$ (Conover 1966). The budget illustrates that $49 \%$ of the carbon removed from suspension by Calanus spp. was immediately released to the DOC pool through sloppy feeding, 31\% was assimilated and $20 \%$ was egested. The leakage of DOC from fecal pellets was only $6 \%$ of the carbon originally removed from suspension, and only $15 \%$ of the carbon remained for potential sedimentation. Higher or lower assimilation efficiency will not influence the fraction of the carbon produced by sloppy feeding, but only the fraction that is assimilated and the fraction in the fecal pellets. The

Fate of carbon processed by Calanus spp.

The estimates of DOC production by sloppy feeding and leakage from fecal pellets were used to model the fate of carbon removed from suspension by Calanus spp. (Fig. 3). Leakage from fecal pellets is assumed to be $28 \%$, the maximum estimated from the regression for C. finmarchicus, since the estimate for C. glacialis did not saturate within the experiment. For the sloppy feeding estimate, the regression estimate for Calanus spp. has been used, i.e. it is assumed that $49 \%$ of the

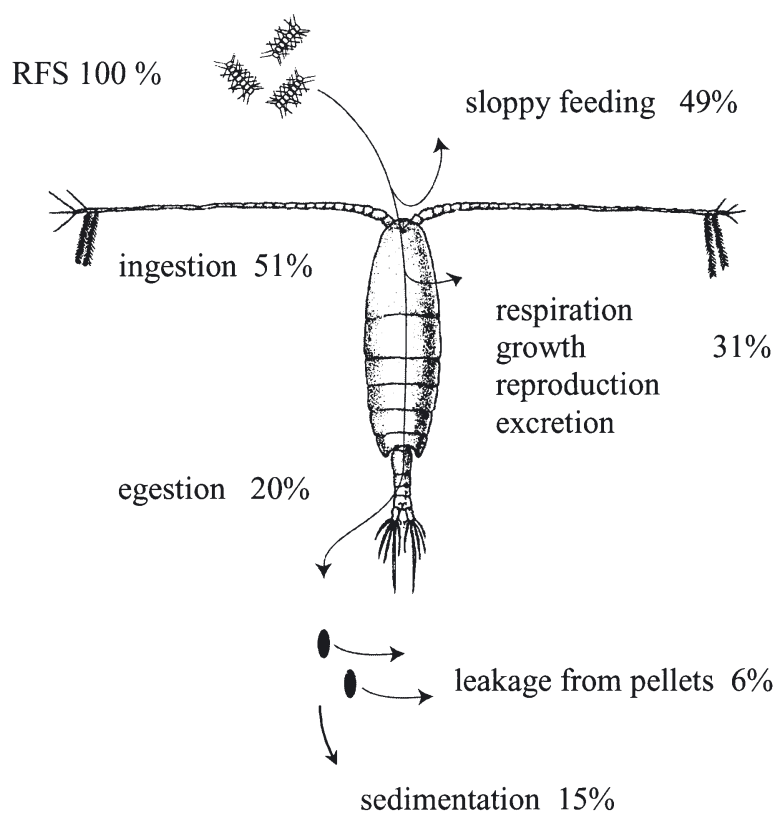

Fig. 3. Calanus spp. Carbon flux of copepods during spring bloom in Disko Bay, western Greenland, showing percentage of carbon removed from suspension (RFS) that ends up in the different pools. See 'Results' for further details reported range of assimilation efficiencies for arctic Calanus spp. is 40 to $87 \%$ (Conover 1966). These efficiencies result in a leakage of DOC from fecal pellets of 9 to $2 \%$ of the carbon originally removed from suspension, while 22 to $5 \%$ of the carbon will be left for potential sedimentation.

\section{DISCUSSION}

The results of the present study emphasize the diverse roles of Calanus spp. in the pelagic food web. These copepods are not only important vectors of carbon transfer to higher trophic levels, but also fuel the bacterial community through production of DOC. To our knowledge, the results presented herein are the first attempt to distinguish and quantify the sources of DOC produced by pelagic copepods.

Our results corroborate the model predictions of Jumars et al. (1989) that a significant leakage from copepod fecal pellets takes place within the first few minutes after release. Within the first hour, fecal pellets produced by Calanus finmarchicus and C. glacialis lost more than $20 \%$ of their organic carbon (Fig. 2). Nevertheless, we found that the amount of DOC produced by leakage from fecal pellets was low compared to the amount produced by sloppy feeding $(6 \%$ compared to $49 \%$, respectively, Fig. 3). This agrees with the suggestions of Hasegawa et al. (2001) and Møller \& Nielsen (2001) that sloppy feeding is the key factor in the large amounts of DOC produced during copepod grazing activity. These studies did not experimentally discriminate between sources of dissolved material, but they did nonetheless show a total release of up to $91 \%$ of dissolved organic or inorganic nitrogen removed from suspension and $69 \%$ of carbon removed 
from suspension, respectively. Strom et al. (1997) found low total DOC production rates and suggested sloppy feeding to be of minor importance when Calanus pacificus were grazing on a relatively small-sized phytoplankton, while Copping \& Lorenzen (1980) found that DOC loss was no higher than $24 \%$ of carbon removed from suspension when C. pacificus grazed on both small- and large-sized phytoplankton species. The results from the latter study could, however, have been biased, as bacteria could have taken up a substantial part of the produced DOC during the relatively long incubation time of $48 \mathrm{~h}$. To our knowledge, the only other study discriminating between DOC produced by sloppy feeding and that produced by excretion and leaching from fecal pellets was performed in freshwater with cladocerans, which differ from copepods in their feeding mode and fecal pellet structure (Lampert 1978). However, in Lampert's study, up to $17 \%$ of the ingested carbon was lost as DOC due to sloppy feeding when the prey was large, while only $4 \%$ was lost when the cells were small enough to be swallowed whole. The contribution of DOC from excretion and leakage from fecal pellets resulted in a total loss of 10 to $17 \%$ of the carbon removed from suspension.

During our study, the experimental conditions mimicked a spring bloom with a dominance of diatoms. The relative importance of the 2 DOC pathways from copepods will vary as a function of seasons. When the available prey is composed of smaller cells, e.g. during summer, DOC production by sloppy feeding will probably be lower and relatively more carbon will be available for assimilation. Moreover, egestion will be greater, thus giving rise to a higher potential leakage of carbon from fecal pellets. However, were sloppy feeding assumed to be zero in the budget in Fig. 3, the DOC leakage from fecal pellets would still only represent $11 \%$ of the carbon removed from suspension. Using a lower assimilation efficiency of $40 \%$ (Conover 1966) will only increase this fraction to $17 \%$. Thus, high DOC production rates by copepods will occur only when the contribution by sloppy feeding is large.

The release rate of carbon from fecal pellets declines after the first hour (Fig. 2), suggesting that most of the solutes have leaked out by this time. Our measurements included the diffusion of DOC from the fecal pellets (Jumars et al. 1989), as well as degradation of POC to DOC by fecal pellet-associated bacteria arising from the intestine. Bacterial degradation was probably insignificant during the $1 \mathrm{~h}$ duration of our experiment (Hansen et al. 1996). However, if fecal pellets were incubated for a longer period, bacterial POC degradation would continue after diffusion has ceased, i.e. more DOC would be released. Previous studies of the leakage and degradation of fecal pellets were not experimentally designed to allow estimation of the importance of leakage during the period immediately following release, as fecal pellets were collected after 2 to $6 \mathrm{~h}$. Hence, conclusions of no detectable leakage from pellets (Strom et al. 1997) may not be correct and the importance of this factor may actually be severely underestimated (Hansen et al. 1996, Urban-Rich 1999, Thor et al. 2003).

It should be noted, however, that the leakage from fecal pellets measured in the present study was probably influenced by the relatively high food concentrations of diatoms in our experiment. High food concentration may lead to faster gut-passage, leaving more solutes in the pellets (Jumars et al. 1989). In addition, low assimilation efficiency has been shown for copepods grazing on diatoms (Besiktepe \& Dam 2002). The phytoplankton concentration in our experiment (Table 1) was, however, not unrealistically high com-

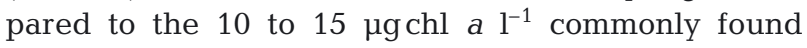
during the spring bloom in Disko Bay (Levinsen et al. 2000), and the maximum value of $31 \mu \mathrm{gchl} \mathrm{a} \mathrm{l}^{-1}$ recorded in the maximum chlorophyll depth during the present investigation (T. G. Nielsen et al. unpubl.). Thus, the observed rates of DOC production from sloppy feeding and leakage of fecal pellets can be considered credible for such a bloom situation.

Another factor that might have biased our rate estimates was the specific labeling of the phytoplankton. Low molecular weight substances, which dominate the cytosol of the phytoplankton cells, are normally labeled first (Nielsen \& Olsen 1989). Non-uniform labeling would, therefore, probably lead to overestimation of sloppy feeding. Furthermore, assimilation in the copepod gut is high for these substances, and leakage from fecal pellets may therefore be underestimated. However, the phytoplankton used in the present experiment was labeled over almost 5 generations, a period suggested by Nielsen \& Olsen (1989) to be sufficient for uniform labeling.

During the spring bloom in Disko Bay, the dominating copepods of the genus Calanus lost almost half of the carbon they removed from suspension as DOC, primarily due to sloppy feeding. In conclusion, the present study stresses the need for a broader view of the role of copepods in the food web. They should be considered not only an essential link to higher trophic levels, but also a significant feedback-link to the microbial food web.

Acknowledgements. The present study was financially supported by the Nordic Arctic Research Programme Grant \# 50031, by the Danish Natural Science Research Council Grant \# 51-00-0415, Grant \# 9801391 and Grant \# 9700196, and by NorFa mobility stipendium \# 010031. The Arctic station Qeqertarsuaq, University of Copenhagen, provided an excellent working platform on land. F. Steffens, captain of RV 'Maja S', provided great technical support. We gratefully 
acknowledge the assistance of B. Søborg, T. Juul-Pedersen, S. Gooding, P. Tiselius, C. Michell and E. Selander in the collection of water and copepods. The manuscript was improved by the constructive criticism of K. Richardson and K. Tang.

\section{LITERATURE CITED}

Besiktepe S, Dam HG (2002) Coupling of ingestion and defecation as a function of diet in the calanoid copepod Acartia tonsa. Mar Ecol Prog Ser 292:151-164

Conover RJ (1966) Factors affecting the assimilation of organic matter by zooplankton and the question of superfluous feeding. Limnol Oceanogr 11:346-354

Copping AE, Lorenzen CJ (1980) Carbon budget of a marine phytoplankton-herbivore system with $\mathrm{C}-14$ as a tracer. Limnol Oceanogr 25:873-882

Eppley RW, Horrigan SG, Fuhrman JA, Brooks ER, Price CC, Sellner K (1981) Origins of dissolved organic matter in Southern California coastal waters: experiment on the role of zooplankton. Mar Ecol Prog Ser 6:149-159

Frost BW (1972) Effects of size and concentration of food particles on the feeding behavior of the marine planktonic copepod Calanus pacificus. Limnol Oceanogr 17:805-815

Hansen BW, Fotel FL, Jensen NJ, Madsen SD (1996) Bacteria associated with a marine planktonic copepod in culture. II. Degradation of fecal pellets produced on a diatom, a nanoflagellate or a dinoflagellate diet. J Plankton Res 18: 275-288

Hansen PJ (1989) The red tide dinoflagellate Alexandrium tamarense: effects on behaviour and growth of a tintinnid ciliat. Mar Ecol Prog Ser 53:105-116

Hasegawa T, Koike I, Mukai H (2001) Fate of food nitrogen in marine copepods. Mar Ecol Prog Ser 210:167-174

Jespersen AM, Christoffersen K (1987) Measurements of chlorophyll a from phytoplankton using ethanol as extraction solvent. Arch Hydrobiol 109:445-454

Jumars PA, Penry DL, Baross JA, Perry MJ, Frost BW (1989) Closing the microbial loop: dissolved carbon pathway to heterotrophic bacteria from incomplete ingestion, digestion and absorption in animals. Deep-Sea Res 36:483-495

Kiørboe T, Møhlenberg F, Nicolajsen H (1982) Ingestion rate and gut clearance in the planktonic copepod Centropages hamatus (Lilljeborg) in relation to food concentration and temperature. Ophelia 21:181-194

Lampert W (1978) Release of dissolved organic carbon by grazing zooplankton. Limnol Oceanogr 23:831-834

Levinsen H, Nielsen TG (2002) The trophic role of marine pelagic ciliates and heterotrophic dinoflagellates in arctic and temperate coastal ecosystems: a cross-latitude comparison. Limnol Oceanogr 47:427-439

Editorial responsibility: John Dolan (Contributing Editor), Villefranche-sur-Mer, France
Levinsen H, Nielsen TG, Hansen BW (2000) Annual succession of marine protozoans in the arctic with emphasis on winter dynamics. Mar Ecol Prog Ser 206:119-134

Maar M, Nielsen TG, Richardson K, Christaki U, Hansen OS, Zervoudaki S, Christou ED (2002) Spatial and temporal variability of food web structure during the spring bloom in the Skagerrak. Mar Ecol Prog Ser 239:11-29

Madsen SD, Nielsen TG, Hansen BW (2001) Annual population development and production by Calanus finmarchicus, C. glacialis and C. hyperboreus in Disko Bay, western Greenland. Mar Biol 139:75-93

Møller EF, Nielsen TG (2001) DOM production by marine copepods: effect of phytoplankton biomass and cell size. J Plankton Res 23:527-536

Nejstgaard JC, Naustvoll LJ, Sazhin A (2001) Correcting for underestimation of microzooplankton grazing in bottle incubation experiments with mesozooplankton. Mar Ecol Prog Ser 221:59-75

Niehoff B, Madsen SD, Hansen BW, Nielsen TG (2002) Reproductive cycles of three dominant Calanus species in Disko Bay, West Greenland. Mar Biol 140:567-576

Nielsen TG, Hansen B (1995) Plankton community structure and carbon cycling on the western coast of Greenland during and after the sedimentation of a diatom bloom. Mar Ecol Prog Ser 125:239-257

Nielsen MV, Olsen Y (1989) The dependence of the assimilation efficiency in Daphnia magna on the ${ }^{14} \mathrm{C}$-labeling period of the food algae Scenedesmus acutus. Limnol Oceanogr 34:1311-1315

Peduzzi P, Herndl GJ (1992) Zooplankton activity fueling the microbial loop: differential growth response of bacteria from oligotrophic and eutrophic waters. Limnol Oceanogr 37:1087-1092

Poulet SA, Williams R, Conway DVP, Videau C (1991) Cooccurrence of copepod and dissolved free amino acids in shelf sea waters. Mar Biol 108:372-385

Roman RM, Ducklow HW, Fuhrman JA, Garside C, Glibert PM, Malone TC, McManaus GB (1988) Production, consumption and nutrient cycling in a laboratory mesocosm. Mar Ecol Prog Ser 42:39-52

Strom SL, Benner R, Ziegler S, Dagg MJ (1997) Planktonic grazers are a potentially important source of marine dissolved organic carbon. Limnol Oceanogr 42: 1364-1374

Thor P, Dam HG, Rogers DR (2003) Fate of organic carbon released from decomposing copepod fecal pellets in relation to bacterial production and ectoenzymatic activity. Aquat Microb Ecol 33:279-288

Urban-Rich J (1999) Release of dissolved organic carbon from copepod fecal pellets in the Greenland Sea. J Exp Mar Biol Ecol 232:107-124

Submitted: April 1, 2003; Accepted: July 15, 2003

Proofs received from author(s): October 31, 2003 